\title{
Formaçáo espectral: do pensamento complexo ao raciovitalismo na formação de professores universitários
}

\author{
Cristina d'Ávila ${ }^{1}$ \\ https://orcid.org/0000-0001-5946-9178 \\ Giovana Zen ${ }^{2}$ \\ https://orcid.org/0000-0001-6405-9843 \\ Denise Moura Guerra ${ }^{3}$ \\ https://orcid.org/0000-0001-5745-7974
}

\section{Resumo}

Este trabalho resultou de uma pesquisa-formação realizada a partir das narrativas reflexivas de docentes, produzidas ao longo do Ateliê didático - projeto vinculado ao programa de formação continuada para docentes universitários (FORPED) da Universidade Federal da Bahia (UFBA). Pretendeu-se com esta pesquisa compreender como a didática sensível repercute na formação de professores universitários. A pedagogia raciovitalista abrange a Didática sensível, tendo como matriz paradigmática a teoria da complexidade (MORIN, 1990) e a fenomenologia raciovitalista (MAFFESOLI, 2005). Optou-se pelo método da pesquisa formaçáo de

${ }^{1}$ Graduada em Pedagogia, possui Mestrado em Educação e Doutorado em Educaçáo pela Universidade Federal da Bahia em 2001. É pós-doutora pela Universidade de Montréal, Quebec, Canadá, na área de Didática (20062007). É Pós-doutora pela Universidade Sorbonne, Paris-De scartes, França (2015-2016). Professora Titular de Didática da Universidade Federal da Bahia e do Programa de pós-graduação em Educaçáo da Universidade Federal da Bahia - UFBA. É pesquisadora do grupo GREAS-CEAQ (Sorbonne, Paris-Descartes). Coordena o Grupo de Estudos e pesquisas em Educação, didática e Ludicidade (GEPEL/UFBA). E-mail: cmdt@ufba.br.

${ }^{2}$ Formação em Pedagogia e Psicopedagogia, com Mestrado em Educação (UNEB) e Doutorado em Educação (UFBA). Professora do Programa de Pós-Graduaçáo em Educaçáo e do Mestrado Profissional em Educaçáo, ambos da Faculdade de Educação da Universidade Federal da Bahia. Integra o Grupo de Pesquisa em Formaçá o de Pro fessores (FEP) e o Grupo de Estudos e Pesquisas em Educação, Didática e Ludicidade (GEPEL). Email: giovanacristinazen@gmail.com.

${ }^{3}$ Licenciatura em Ciências Biológicas pela Universidade Federal da Bahia (1986); Bacharelado em Ciências Biológicas pela Universidade Federal da Bahia (1990); Mestrado em Educação pela Universidade Federal da Bahia (2004); Doutorado em Educação pela Universidade Federal da Bahia (2009). Atualmente é professora Adjunta da Universidade Federal da Bahia; Vice- 1\&iacute ; der do Grupo de Pesquisa FORMACCE em Aberto, Coordenadora do Observatório Avançado de Currículo e Formação do FORMACCE, Coordenadora do Grupo de Estudos em Currículo e Formaçáo do FORMACCE e Membro da Associaçáo Brasileira de Currículo $-\mathrm{ABdC}$. 
abordagem qualitativa. O contexto da pesquisa constituiu-se de 25 professores inscritos nas turmas dos ateliês didáticos de 2016 a 2019. Os sujeitos produziram seus diários formacionais no período mencionado e 14 responderam ao questionário de avaliação diagnóstica, no ano de 2019. A análise dos dados produzidos foi baseada na técnica da análise de conteúdo (BARDIN, 2010), que orientou a definição dos seguintes eixos analíticos: a) o perfil dos professores/cursistas do Ateliê; e b) reverberaçôes da didática sensível sobre a formação. Verificou-se nas narrativas dos professores a presença marcante da linguagem lúdica e estética, reiterando, assim, as reverberaçóes da didática sensível em seus processos formativos, em suas identidades profissionais e profissionalidades.

Palavras-chave: Ateliê didático, Docência universitária, Didática sensível, Raciovitalismo, Pensamento complexo.

\section{Spectral formation: from complex paradigm to raciovitalism in the training of university professors}

\section{Abstract}

This work is the result of a research-training carried out from the reflective narratives of teachers in training, produced throughout the didactic workshop - project linked to the continuing education program for university teachers (FORPED) at the Federal University of Bahia (UFBA). The aim of this research is to understand how sensitive didactics affect the training of university professors. Raciovitalist pedagogy encompasses sensitive didactics, having the theory of complexity as a paradigmatic matrix (MORIN, 1990) and raciovitalist phenomenology (MAFFESOLI, 2005). The research context consists of 25 teachers enrolled in the classes of didactic workshops in 2016, 2017, 2018 and 2019, participants who wrote their training diaries in the mentioned period, and 14 who answered the diagnostic assessment questionnaire, in classes 6 and 7 in 2019. The analysis of the data produced was based on the content analysis technique (BARDIN, 2010), which guided the definition of the following analytical axes: a) the profile of the Ateliê teachers / course participants; and b) reverberations of sensitive didactics about training. It is notorious to verify in the teachers' narratives the striking presence of playful and aesthetic language, thus reiterating the reverberations of sensitive didactics in their formative processes, in their professional identities and professionalities.

Keywords: Didactic atelier, University teaching, Sensitive didactics, Raciovitalism, Complex paradigm.

\section{Introduçáo}

Espectro: "No âmbito científico um espectro é uma representação das amplitudes ou intensidades - o que geralmente traduz-se por energia - dos componentes ondulatórios de um sistema quando discriminadas uma das outras em função de suas respectivas frequências." 
Espectral: [adjetivo] relativo a ou próprio de variáveis, grandezas ou propriedades utilizadas na descrição dos niveis do espectro de um observável físico. [Física] Relativo ao espectro luminoso: análise espectral. ${ }^{4}$

O conceito de espectro ou de um fenômeno espectral alude à ideia de "amplitude ou intensidades"; na Física, um fluxo luminoso de energia de longo alcance. Assim, consideramos tal metáfora por remeter a ressonância dos ideários da complexidade e da teoria raciovitalista sobre um projeto de formação de professores empreendido na Universidade Federal da Bahia desde o ano de 2016.

$\mathrm{O}$ ateliê didático é o nome deste projeto que tem à frente uma equipe de professores da mencionada universidade; um projeto de formação que se erige sobre três pilares fundamentais: a didática sensível (que vincula-se à pedagogia reciovitalista e à epistemologia complexa), a epistemologia da prática (formaçáo ancorada na experiência profissional dos professores partícipes) e a fenomenologia existencial que transcende as histórias de vida como lastro pelo qual os professores ao narrarem e evocarem as próprias histórias ressignificam conceitos fundantes em suas profissionalidades.

Um dos maiores problemas que acercam a docência universitária no contexto da educação brasileira, diz respeito à lacuna na formação pedagógica, revelando a falta de formação específica para a docência universitária. (CUNHA, 1998; VEIGA, 2012; PIMENTA e ANASTASIOU, 2002; D'ÁVILA, 2015, 2016, 2018). Içados à condição de docentes, estes profissionais da educação superior, que atuam como técnicos em suas áreas disciplinares específicas, recorrem à socialização pré-profissional como manancial de onde sorvem a própria didática. Numa espécie de autodidatismo pedagógico, em efeito dominó, o despreparo na área aludida reverbera na prática pedagógica destes docentes, em suas relaçóes pedagógicas com os alunos e pares, em suas identidades profissionais e profissionalidades.

A legislação brasileira é praticamente omissa em relação a tal formação, basicamente resumindo-a a 60 (sessenta) horas de carga horária em disciplinas de formação didático-pedagógica, em cursos de "metodologia do ensino superior" (Resolução $\mathrm{N}^{\circ} 12 / 83$, do CFE, Art. 40 ), ou, como reza a Lei

\footnotetext{
${ }^{4}$ Dicionário online de língua portuguesa. Disponível em: https://www.dicio.com.br/espectral/. Acesso em: 31 de agosto de 2020 .
} 
9394/96 (1996, art. 66), este corpo docente terá sua formação assegurada primordialmente através de cursos de Mestrado ou Doutorado (strictu senso). O problema é que muitas vezes estes cursos não trazem em seus currículos qualquer disciplina voltada ao conteúdo da formação didático-pedagógica.

O projeto do ateliê didático se institui com a perspectiva de mitigar o problema no âmbito de nossa Universidade. Um projeto vinculado ao programa de formação continuada para docentes universitários (FORPED), empreendido pela Pró-reitoria de Graduação (PROGRAD) em parceria com a Pró-reitoria de Desenvolvimento de Pessoas (PRODEP).

Pretende-se com a presente pesquisa, compreender como a didática sensível, que tem suas bases epistemológicas vinculadas à pedagogia raciovitalista (pedagogia inspirada na teoria da razão sensível de Michel Maffesoli (2005), e no pensamento complexo de Edgar Morin (1990) repercute na formação de professores universitários, mediante seus relatos a partir de questionários e diários formacionais online. As questóes que balizaram o estudo foram as seguintes: como se caracteriza o perfil dos professores partícipes do ateliê? como percebem a docência? o que esperam do ateliê didático? como a didática sensível (e pedagogia raciovitalista), mobilizada como abordagem, tem repercutido na formação dos professores? Estas questôes nos impulsionam para o campo empírico em busca de possíveis respostas que apontem para novas possibilidades de formação.

\section{Metodologia e contextualizaçáo da pesquisa}

Este trabalho resulta de uma pesquisa-formação de abordagem qualitativa, realizada a partir das narrativas reflexivas dos docentes em formação, produzidas nos diários formacionais online ao longo do projeto Ateliê didático. A pesquisa-formação em pauta, de base fenomenológica e crítica, emerge como dispositivo que amplia as possibilidades de compreensão da experiência formativa pelos copartícipes da pesquisa: formandos e formadores/pesquisadores. Trata-se de uma investigação que acontece concomitante à formação, na qual, "todos os sujeitos envolvidos formam e se formam em contextos plurais de situaçóes de trabalho e aprendizagem" (SANTOS; WEBER, 2018, p.29). Depreende-se, ainda, dessa pesquisa, a valorização intercrítica da experiência e do vivido como reflexóes seminais para a ressignificação da própria prática (MACEDO, 2006). 
O contexto da pesquisa constitui-se dos ateliês didáticos conduzidos em 2016, 2017, 2018 e 2019. São população da pesquisa, 25 professores que participaram dos ateliês didáticos no período mencionado e 14 que responderam ao questionário de avaliação diagnóstica, nas turmas 6 e 7 no ano de 2019.

O Ateliê Didático tem se constituído em potente dispositivo de formação continuada. Uma formação marcada pela interação de subjetividades e compartilhamento de saberes da experiência, articulados a uma formulação teórica, pautada na didática do sensível, na epistemologia da prática e na fenomenologia existencial. Essa experiência formacional congrega professores de diferentes áreas de conhecimento que, no encontro, produzem, sistematizam saberes e constroem realidades voltadas a uma docência ampliada, "autêntica" (BALL, 2005). Nesse caso, a "escuta sensível" (BARBIER, 2002) e o espaço de partilha são aspectos fundantes da formação supracitada.

Iniciamos o projeto Ateliê Didático em junho de 2016 com um coletivo de cinco professoras formadoras, três da área da didática e duas do campo do currículo que, mobilizadas pelos estudos e pesquisas sobre a docência universitária e em ato de complementariedade de contribuiçóes, fizeram acontecer a primeira edição do Ateliê Didático, no formato de curso de 40 horas, sendo $30 \mathrm{~h}$ presenciais e $10 \mathrm{~h}$ online. Nas últimas ediçóes, foi feito um ajuste na carga horária, passando para $40 \mathrm{~h}$ de atividades na modalidade presencial e 20 na modalidade online.

Assumimos uma formação pautada em processos de implicação colaborativa, na qual os formandos pudessem produzir, a partir da compreensão sensível das suas demandas, itinerâncias de autorização, de construção de saberes sobre a própria docência. As atividades presenciais e online são marcadas pela interação, colaboração, cocriação nos processos de formação, conhecimento e aprendizagem. Outrossim, é no âmbito da estética do sensível que docentes formadores e formandos ressignificam saberes e criam condições para tomada de decisão sobre a docência universitária. No bojo do ateliê, os participantes são desafiados a produzirem um diário de formação no qual podem narrar aprendizagens, sentimentos, impressóes sobre as discussões realizadas e suas reverberaçôes no trabalho com os estudantes. Além do diário formacional, utilizamos outro dispositivo avaliativo/formativo que constitui a ressignificação dos planos de ensino dos professores. Nesse 
Semestre Suplementar em 2020-2, devido à pandemia, atuaremos num cenário totalmente online. Um desafio sem precedentes para professores formados e formadores na modalidade presencial, raras exceçóes para experiências com a cultura digital. Nesse sentido, mergulhamos no estudo sobre o ensino e a aprendizagem na modalidade online e estamos em fase de planejamento do décimo primeiro Ateliê Didático, reconfigurado para o ambiente totalmente digital.

A concepção pedagógica que está na base do ateliê didático, é a Pedagogia Raciovitalista, aliada à epistemologia da prática (ancorada na experiência profissional) e à fenomenologia existencial (ancorada das histórias de vida). Neste artigo vamos nos ater à teoria raciovitalista e a Didatica sensível que dão esteio ao fazer docente formacional.

\section{Raciovitalismo e pensamento complexo: as âncoras da didática sensível}

A pedagogia raciovitalista abrange a Didática sensível. A Pedagogia raciovitalista sorve de variadas fontes, tendo como matriz paradigmática fundamentalmente a teoria da complexidade de Edgar Morin (1990) e a fenomenologia raciovitalista de Maffesoli (2005). São sínteses capazes de colher as centelhas que se complementam e que se podem coadunar em um novo conhecimento pedagógico-didático (MORIN, 1990; MAFFESOLI, 2005).

Essa Pedagogia está atravessada pela compreensão de que o tecido social se constitui em interpretações para além das dicotomias que se edificaram com a ciência moderna, em que pesem todos os avanços experimentados com o racionalismo de René Descartes (Cartesius) e com o positivismo de Augusto Comte, cada um à sua época. O racionalismo cartesiano irrompeu de forma decisiva contra o pensamento dogmático religioso no contexto da Renascença e cindiu com as certezas tradicionais nos séculos XVI e XVII. E o positivismo comtista do século XIX transpóe para a sociologia o método causal das ciências naturais. Essas duas correntes filosóficas estão na base da ciência moderna que ao ressignificar o conhecimento em disciplinas científicas, fez avançar a sociedade rumo a conquistas importantes nas várias áreas do saber. Os séculos XIX e XX foram pródigos em avanços científicos sem precedentes históricos: a revolução industrial, as ferrovias, a eletricidade, o telefone, o rádio, a televisão, os computadores e finalmente a Internet no século XX. Todavia 
corroborou com a visão dicotômica e hegemônica que separa arte e ciência, razão e sensibilidade acentuadamente vivenciadas em todo o século XX com influência marcante nos dias atuais. $\mathrm{O}$ princípio da separação não morreu. $\mathrm{O}$ princípio analítico é importante. Porém não é suficiente. É preciso separar, mas também reunir. É preciso analisar, mas também sintetizar.

$\mathrm{O}$ paradigma complexo como teoria subjacente a nossa pedagogia, parte de princípios que incluem pensamento analítico e sintético com os quais corroboramos. O complexo não é simplesmente sinônimo de algo complicado. Essa acepção clássica é questionável quando nos deparamos com os exemplos no campo da matemática (números complexos, algoritmos), da química, da física quântica e da cibernética, ciências que tem prodigalizado os princípios de integração da inter e transdisciplinaridade. Complexo, na perspectiva adotada por Morin, significa o que é entretecido junto, favorecendo a imagem rizomática que está em sua base. É uma compreensão da totalidade social abrangente e não hierárquica, pela qual o todo não representa simplesmente a soma das partes. O todos está nas partes, assim como as partes contém o todo. Ardoino (2002, p. 551) afirma que: "O conjunto interativo (sistema que funciona como uma rede) deixará entrever, mais profundamente, hierarquias entrelaçadas a partir das quais serão representados efeitos contrariantes, até mesmo antagônicos, que, entretanto, não proíbem a manutenção da coerência do discurso científico. "

O pensamento complexo rompe com o paradigma positivista de ciência e propóe outra epistemologia assentada sobre alguns princípios fundamentais. $\mathrm{O}$ princípio da dialógica sustenta a ideia de que as compreensóes contraditórias não se repelem, mas podem ser complementares entre si. É um principio que questiona a ordem imutável das coisas na explicação do universo, da natureza, da sociedade, como no caso de várias teorias científicas que transformaram mundo e que se transformaram. $\mathrm{Na}$ perspectiva do pensamento complexo, com o princípio da dialógica, a ordem pressupóe a desordem e uma nova organização das ideias.

O princípio da separação dá lugar à compreensão do todo e das partes como concepção insurgente no século XX: o todo é maior que a soma das partes. Essa perspectiva nos conduz a ideia de organização que produz emergências e que, nas partes, produzem outras totalidades. O princípio da certeza absoluta cede lugar às incertezas, um conceito bastante caro para o pensamento complexo. 
A epistemologia complexa pressupóe retroações, outro principio importante. Reconhece a desordem e a eventualidade das coisas. "É o fim do saber absoluto e total. A complexidade repousa sobre o caráter do tecido e sobre a incerteza", assevera Morin (2002, p. 564). Corrobora o raciovitalismo pedagógico porque este se erige num campo de incertezas também, num campo de compreensóes abrangentes, reconhecendo a efemeridade das explicaçóes lógicas e se baseando na dialógica e nas visões plurívocas do real.

Do ponto de vista eminentemente didático-pedagógico no concentremos na abordagem sistêmica. Da complexidade associada à abordagem sistêmica resulta a compreensão da organização de conteúdos náo somente pela análise, mas também pela síntese. Semelhante pensamento complexo, o raciovitalismo preconizado por Michel Maffesoli (2005), parte da crítica à visão dualista tão em voga no pensamento racionalista moderno: o bem e o mal, a razão e o sensível, arte e ciência. O autor citado propóe uma análise social com base na dimensão sensível e agregadora do ser, numa visão das pulsóes, das paixóes, das atraçóes, finalmente, da estesia que lhe é imanente.

Para a Pedagogia raciovitalista, esse ambiente emocional presente no tecido social, está presente também na sala de aula, um espaço em que é preciso deixar emergir as subjetividades e não apenas os processos cognitivos. A educação nessa perspectiva está para além da instrução racional dos fenômenos, supera o explicacionismo e transcende o pensar abstrato para o sentir-pensar-agir, numa tríade. Entende que o pensar racional faz parte do aprender e do ensinar, mas sempre associado às pulsóes emocional e intuitiva como partes imanentes do ser humano.

O papel da instituição de ensino nesta pedagogia é propiciar ao educando autonomia, autoria, pensamento crítico e criativo. Necessariamente nessa pedagogia, o acesso ao conhecimento é democrático e se deseja a sua ampla distribuição, aliada a uma apropriação significativa e útil à vida cotidiana e futura. O conhecimento como dito, é concebido como produção da humanidade e seu processo de apropriação passa pela capacidade sensível e inteligível, melhor explicado adiante quando falamos da Didática sensível. O processo de mediação dos conteúdos e gestão da classe, assim como os métodos avaliativos, compreendem, de forma integrada, que são processos que emanam das capacidades inteligíveis e sensíveis dos educandos e devem ser 
trabalhados didaticamente visando a emancipação, a aprendizagem crítica, a capacidade criadora, o uso funcional do conhecimento na vida de cada um.

\section{Didática sensível}

A didática (do) sensível emana da necessidade de reequilíbrio entre corpo e espírito, razão e sensibilidade, arte e ciência. Os princípios raciovitalistas que estão na base também da didática sensível são: a Razão interna (1) uma racionalidade aberta e oposta ao racionalismo estático; o Pensamento orgânico (2) enquanto pensamento vivo e pulsante com uma dinâmica própria e ânima interna; um pensamento globalizante sobre os fenômenos que não cinde, mas incorpora as emoções e as razões, unidimensional e plural; a Intuição (3) vista não como qualidade unicamente psicológica, mas como importante vetor do conhecimento, como uma sabedoria que participa do inconsciente coletivo; o Saber sensível (4) advindo da estesia (ahisetesis para os gregos) que significa sentir, para além do que a razão abstrata garante ao pensamento inteligível. O saber sensível permite o pensar com a corporeidade, com a imaginação, com a intuição. Um sentir incorporado que permite a visão totalizadora e que abrange os demais princípios.

A Didática Sensível que traz para dentro de si mesma a subjetividade humana. O reconhecimento de que pensamos também com as emoçôes, e aprendemos a partir de múltiplo canais. Razão pela qual, do ponto de vista das aprendizagens e concepção de inteligência, nos apoiamos na Teoria das inteligências múltiplas (Gardner, 1994). Na didática sensível, o que os olhos veem, o coração sente e o cérebro processa. $\mathrm{O}$ que o corpo apreende, a intuição sente e o cérebro decodifica em signos racionais. Trata-se de uma racionalidade que rompe com a racionalidade instrumental, pela qual o sujeito apreende o mundo apenas através do raciocínio lógico, unicamente. A sensibilidade a que nos referimos é também um tipo de inteligência que presumimos associada à inteligência cognitiva. Não se trata da substituição de uma racionalidade por outra, mas de uma racionalidade que associa o sensível ao inteligível.

A operacionalização da didática sensível é regida pelos princípios:

A. Sentir / intuir: possibilitar o escutar, ver, tocar, intuir; 
B. Metaforizar / imaginar: criar modos de intervenção didática a partir de múltiplas linguagens artísticas e lúdicas, a fim de provocar a imaginação e o pensamento lúdico criativo;

C. Experivivenciar / problematizar: a partir de situaçóes construídas, visa aguçar o raciocínio, o desejo de responder a situaçóes problematizadoras e dilemáticas.

D. Ressignificar / sintetizar: produzir sínteses, emitir um significado pessoal aos objetos de conhecimento.

E. Criar / recriar: estimular e permitir o emergir de novas compreensóes, construção do novo conhecimento e atitudes.

$\mathrm{O}$ primeiro princípio - Sentir/intuir - se refere às atividades que possibilitem ao sujeito sentir o conhecimento e apreendê-lo pelas vias sensoriais e/ou pela apreensão sutil mediada por metáforas criativas, vendo, tocando, escutando, intuindo, se emocionando. Para tal o trabalho com as metáforas o lúdico e o estético são dimensões fundamentais.

O segundo, a metaforização, está presente no mundo simbólico do cotidiano: pode estar num poema, num rap, no funk, numa obra de arte visual, numa pintura, ou escultura, assim como nos diversos símbolos e códigos que circundam a vida social. A metáfora, constitui pois uma categoria imprescindível no pensar orgânico do raciovitalismo, pois auxilia na compreensão das sutilezas do existir humano e está impregnada em nosso modus operandi - na compreensão das coisas, acontecimentos, como emergem, como estão no mundo. O procedimento didático do Metaforizar, parte quase sempre de algum estímulo estésico (do sentir) ou estético (artístico ou lúdico), a fim de que os partícipes entrem num estado de abertura para a apreensão, compreensão e ressignificação dos objetos de conhecimento. A metáfora, através da imagem "proporciona a apreensão das coisas, dos fenômenos, do existir, desde dentro de suas teias entrelaçadas, de suas ambiguidades e polifonias.

O terceiro princípio - o experivivenciar problematizando - parte da problematização do conhecimento a partir da experiência pregressa do educando, aliando o saber previamente construído ao novo conhecimento. Aguça o pensamento lógico, cria nexos, redes amplas de significados. Uma só pergunta já mobiliza o estudante na tentativa de respondê-la. Qual enigma, a problematização do conhecimento mobiliza o raciocínio lógico, diverte, e 
conduz cada sujeito a sua própria caminhada intelectual em direção a possíveis soluçóes postas.

A ressignificação e a síntese constituem o quarto princípio, visam provocar o emergir de novas compreensóes, a transformação do conhecimento que foi apropriado sob outros e novos pontos de vista. Pontos de vista com significados pessoais. Ressignificar o conhecimento parte de um movimento de análise-síntese, de um estado de consciência focado para um estado de consciência ampliado, como diz Luckesi (2004). É preciso atribuir sentido ao que se está aprendendo e ao mesmo tempo - ou na sequência -, isso não tem uma ordem exata, produzir sínteses, uma visão do todo e não somente das partes.

A criatividade ou o pensar criativo que constituem o quinto princípio, náo decorre apenas de fatores intrapsíquicos, de natureza cognitiva ou relativa à personalidade e motivação, mas também sofre influência marcante de fatores ambientais e sociais. Assim sendo, o meio sociocultural é determinante: valores familiares, habitus e o contexto educacional são fatores fortes a influenciar o potencial criador. Este é um conceito polissêmico para o qual náo existe uma única definição. Com este princípio visamos estimular o emergir de novas compreensóes e condutas e criação autoral de um pensamento próprio, autônomo: um conceito, uma teoria, um processo ou um produto. A criação no ato didático pedagógico são construçóes autônomas, plenas de autoria, só realizáveis em contextos onde haja entrega ao processo e trabalho intenso pelos discentes e docente.

Interessa-nos, sobremaneira, vislumbrar como a Didática sensível advinda do pensamento pedagógico raciovitalista impregnou a formação dos professores que participaram dos ateliês didáticos. Para tal, analisamos questionários e diários de formação dos cursistas. Traremos aqui alguns desses resultados com a ambição de dialogar com eles.

\section{Resultados da pesquisa: ressonâncias da dimensảo sensível na formaçăo docente}

Para análise das informaçóes nos baseamos na técnica da análise de conteúdo (BARDIN, 2010) e partimos de unidades de significação ou eixos analíticos que conduziram nosso olhar: a) o perfil dos professores/cursistas do Ateliê; e b) reverberaçóes da didática sensível sobre a formação. Analisamos o conteúdo das escritas nos diários formacionais online elaborados por 
professores que participaram do ateliê nos anos de 2016, 2017, 2018 e 2019 . Analisamos também os dados provindos das questôes abertas obtidas através de questionário aplicados às duas turmas do ano de 2019, antes que os professores tivessem cursado a formação do Ateliê didático.

Os professores que participam do Ateliê Didático provêm de campos disciplinares, os mais variados. Neste estudo temos a presença de 20 cursos disciplinares distintos: Dança, Enfermagem, Nutrição, Odontologia, Direito, Ciências Sociais/Estudos sobre Gênero, Veterinária, Biologia, Engenharias, Farmácia, Nutrição, Pedagogia, Música, Medicina, Comunicação social, Licenciatura em Desenho e Plástica, Bacharelado Interdisciplinar Ciência, Tecnologia e Inovação, Física, Geofísica, Geologia. Entre os participantes é possível identificar aqueles que integram o quadro de docentes da UFBA há poucos meses e aqueles que já estão próximos da aposentadoria. Os professores respondentes, quando indagados sobre as razóes pelas quais escolheram a docência universitária, a maioria (perto de $80 \%$ ) respondeu que tinha o desejo de atuar como professores. Os demais geralmente indicam que o magistério superior foi uma contingência num determinado momento da trajetória profissional. Esse dado contradiz o que se observa no contexto acadêmico, no qual a maioria dos docentes se identifica muito mais como especialistas da área do que como professores. Talvez esse seja um perfil preponderante dos docentes que buscam o Ateliê Didático, profissionais que de algum modo já vislumbravam a docência universitária como profissão.

Ainda que manifestem desejo e interesse pelas discussões pedagógicas, poucos são os docentes que já leram algo relacionado ao tema ou realizaram uma formação na área. Entre as referências citadas, Paulo Freire é sem dúvida a leitura mais acessada pelos docentes que já possuem alguma leitura no campo pedagógico. Diante da pergunta sobre as razóes pelas quais decidiram realizar o Ateliê Didático, $100 \%$ dos participantes desejam aprimorar a sua prática como professores. Alguns também destacam a importância da interlocução com os pares. Nas respostas, algumas concepçóes sobre o ato de ensinar já são evidenciadas, como por exemplo, 'para ter acesso a técnicas didáticas mais adequadas para eu me tornar um professore melhor'. Logo nos primeiros encontros eles percebem que as discussóes não se restringem às técnicas de ensino e comentam: "estou me surpreendendo porque estou aprendendo além de minhas expectativas" 
No início do Ateliê Didático os docentes também são questionados sobre as principais dificuldades enfrentadas ao ministrar uma aula. A resposta mais recorrente, nas turmas pesquisadas (40\%) está relacionada à necessidade de manter a atenção e o interesse dos alunos durante a aula. Por trás dessa resposta pode haver um interesse genuíno dos docentes em implicar os estudantes cada vez mais nas atividades propostas durante o componente curricular. Por outro lado, também pode representar apenas a necessidade de manter os alunos atentos para as sucessivas exposições que são realizadas durante o semestre letivo, como neste exemplo: "minha principal dificuldade é manter os alunos atentos para dar conta de todo o conteúdo previsto em tão pouco tempo; me falta poder de síntese, quero passar tudo que tenho no meu "arsenal" de conhecimento". Poucos são os professores que de fato indicam como principal dificuldade as suas próprias concepçôes sobre o ato de ensinar e de aprender. Além da suposta dispersão dos estudantes, os docentes também indicam como dificuldade o manejo de alguns recursos como o quadro branco ou determinados artefatos digitais.

Outro questionamento realizado no início do Ateliê Didático refere-se ao reconhecimento de potencialidades pelos próprios docentes. Neste ponto também se explicitam algumas crenças dos participantes que são levadas em consideração ao longo do curso. Observa-se nesse item o predomínio de práticas transmissionais entre os docentes: "bom domínio do conteúdo", a "comunicaçâo", a "facilidade para explicar conceitos", "aptidão para o convencimento", "passar o assunto com clareza" e "paciência com os alunos que apresentam dúvidas".

As expectativas acerca do que esperam conhecer e aprender durante a realização do Ateliê Didático é o último questionamento feito aos docentes no início do curso. A imensa maioria dos participantes manifesta interesse em conhecer técnicas didáticas e metodologias ativas. Na sequência, o aspecto mais citado é a avaliação da aprendizagem. Os professores explicitam neste momento o anseio em aprender a utilizar diferentes instrumentos de avaliação.

Quanto ao segundo eixo de análise - reverberaçôes da didática sensível sobre a formação - a partir dos diários online, elencamos as falas de 25 professores numa amostra aleatória, mas bastante representativa. Não tivemos o objetivo de provar os efeitos de um curso na formação dos pares, mas de ilustrar a força da abordagem pedagógica adotada neste processo. $\mathrm{Na}$ perspectiva da pesquisa-formação de abordagem fenomenológica, mais vale 
descrever para melhor compreender o fenômeno. Tomamos de empréstimo o que diz Larrosa (2002, apud Perez e Miguel, 2016), sobre o valor que tem as narrativas em si,: "[...] a experiência não é o caminho até um objetivo previsto, até uma meta que se conhece de antemão, mas é uma abertura para o desconhecido, para o que não se pode antecipar nem "pré-ver" nem "prédizer." Não sendo possível por escassez de espaço trazer todas as escritas em sua extensão, optamos por excertos para que o leitor melhor compreenda o processo.

\section{Discussáo dos resultados}

Os relatos falam por si. Percebe-se das falas que a abordagem sensível da pedagogia e didática adotadas reverberam na formação dos professores que compóem esta amostra.

O texto de Rubem Alves, as Técnicas de relaxamento, as músicas de Bach nos mostraram que somos humanos e precisamos do sensível para fazer da nossa prática docente uma prática libertadora. (DL, 2019).

Quanto mais participamos, mais nos sentimos parte desse processo de criação, que é criativo e nos mobiliza com alegria. O Ateliê é mesmo constituído pela "epistemologia da prática, dimensão sensível e fazer criativo, possibilitando aos participantes a abordagem e vivência de conceitos didático-pedagógicos (RA, 2018)

A aula foi gratificante. $\mathrm{O}$ apelo sensorial e as informaçóes trocadas entre os participantes fazem a diferença na construção de uma aula. certo que muitas das praticas apresentadas seráo aproveitadas por muitos dos participantes, incluindo eu em minhas disciplinas. J.M.F., Medicina, 2018

No final do dia, projetei para o futuro a inclinação para a concepção crítica-construtiva e que ao mesmo tempo seja mais intuitiva com uso da didática sensitiva e lúdica (VF, 2019).

São relatos que apontam para um ganho de consciência, a nosso ver. De uma consciência que extrapola um saber técnico profissional e evocam reverberaçóes sobre as concepções paradigmáticas desses docentes. 
Também de acordo com as afirmaçóes sinalizadas em seguida , pode-se perceber o quanto a abordagem lúdica e sensível utilizadas marcaram a trajetória dos professores durante o processo formativo. CS afirma a força da atividade na ressignificação de sua identidade profissional, assim como MB se apercebe do mesmo aspecto:

[...] a atividade estimulou a reflexão e a sensibilização sobre qual seria o ideal pedagógico realizável em nossa práxis pedagógica como docente, conduzindo para a ressignificação de nossas identidades profissionais como docentes, frente a aprendizagem vivencial de conhecimentos e saberes didático-pedagógicos.(CS, 2019).

Muito interessante a proposta de confecção das mandalas. Cada uma representando a identidade de alguém, impregnada por seus saberes e práticas pedagógicas... (MB, 2017)

As atividades lúdicas provocaram transformações nos modos de ver a profissão e as profissionalidades dos docentes envolvidos, seus saberes profissionais. Saliente-se nas falas de DP (2019) e FLA, (2017), a importância das trocas no coletivo dos próprios professores. Isso tem muito a ver com as histórias de vida, próprias da fenomenologia existencialista que compóe a abordagem pedagógica raciovitalista empregada.

Uma construção que nos levou ao chão da sala de aula, com o lúdico dos cortes, cores, desenhos e rabiscos. Discutindo os desafios para a implementação dessa ou daquela concepção dentro das diferentes áreas de atuação. De fato, foi muito enriquecedor. Em mim, produziu fome. (DP, 2019)

A atividade lúdica desenvolvida na sala de aula me tocou profundamente, uma vez que percebi que minhas angústias e obstáculos enfrentados em sala de aula são semelhantes aos vivenciados por outros professores." (FLA, 2017)

A importância da intuição na formação, próprio da racionalidade sensível é colocado por Ka (2017). E L (2016), se vê de forma consciente, sem estar presa a qualquer corrente, mas com abertura para uma busca que integre o saber, o sentir e o ser. 
Muitos conceitos já eram conhecidos em parte e me marcou mais a valorização do processo intuitivo como bagagem prévia e experienciada do aprendiz, que se mescla à razáo lógica cientificista e a extrapola, quando ao contextualizar gera reflexão e convida à retornar à realidade. (Ka, 2017)

Náo defendo ou estou presa a nenhum pensamento, linha ou corrente de forma integral/ única, ainda que os conceitos mais contemporâneos e integram o saber, o sentir e o ser; a sensibilidade, a razão e uma prática coerentes sejam a minha busca. (L, 2016).

Transformações que são levadas para a práxis:

Depois desse ateliê não posso mais fechar os olhos para tanta coisa errada que eu vejo dentro da minha unidade e isso de certa forma tem me trazido alguns problemas com meus pares. (AM, 2018)

Assim, a formação permeada pelo conteúdo e experiências pessoais conduz ao aprendizado pleno e repleto de significação, o que torna possível a formação adequada a realidade social. Nesse contexto, o professor possibilita a reflexáo e conscientização, bem como a autonomia de seus alunos. (TD, 2018)

Assim, observa-se que a concepção raciovitalista adotada deixou marcas nos processos formativos dos professores que compóem o público do Ateliê, dando-nos conta, de forma incisiva que, nesses processos, mais valem as mudanças paradigmáticas que impulsionam transformações nas formas de condução das aulas do que uma formação baseada em conteúdos exclusivamente técnicos. Cursos baseados em saberes técnicos podem auxiliar na forma, nos métodos, mas se não se coadunam com concepçôes pedagógicas e epistemológicas não transformam efetivamente as práticas em práxis pedagógicas.

\section{Consideraçóes finais}

Neste artigo trouxemos à baila uma experiência exitosa de formação pedagógica de docentes universitários a partir de uma abordagem inovadora. Baseados na pedagogia raciovitalista que tem seus fundamentos no 
pensamento complexo, o processo formacional no Ateliê didático se erige e deixa marcas. Deste ideário advém a Didática sensível que lastreia as açóes pedagógico/didáticas do Ateliê. Além desta, a epistemologia da prática (TARDIF, 2002) que ancora-se nas experiências profissionais dos docentes em formação e a epistemologia existencialista (NOVOA, 2001) que sustenta os diários formacionais elaborados pelos docentes e demais metodologias apoiadas nas histórias de vida, compóem a tríade estruturante do ateliê didático e presidem as açóes pedagógico/didáticas.

Nesse sentido, a linguagem estésica e estética, além da dimensão lúdica que transversaliza nosso fazer formacional, são sempre lembradas pelos docentes encharcando os relatos presentes neste artigo. Elencamos excertos das falas dos docentes que traduzem essas reverberaçóes buscando responder aos nossos objetivos. É notório verificar nos relatos dos professores, em seus diários formacionais, a presença marcante da linguagem lúdica e estética nas experiências vivenciadas no sentido positivo da influência do raciovitalismo e didática sensível em seus processos formativos, em suas identidades profissionais e profissionalidades. Além disso, as transformaçóes relatadas nas práxis dos professores.

Há variados fatores que intervêm na formação positiva dos partícipes do ateliê, compreendendo: as trocas entre os pares (daí a importância da dialogia freireana em nossa condução), a vivência dos conteúdos a partir da experiência profissional (próprio da didática sensível); o mergulho nas subjetividades em metodologias baseadas nas histórias de vida (fenomenologia existencialista); a linguagem artística e lúdica que permeia a condução metodológica (didática sensível); a automotivação dos participantes que se inscrevem voluntariamente nos ateliês já em busca de algo que preencha as lacunas da falta de uma formação pedagógica, aliada às competência técnica, política e sensível da equipe de formadores. A nosso ver, estes são fatores que, de certo modo, explicam a importância dos ateliês na formação continuada dos docentes. Outras evidências devem existir mas escapam a nossa compreensão no momento. A pesquisa reitera nossas convicçóes e nos convida a novos mergulhos nesse processo formacional sensível, lúdico, crítico, criativo e transformador que chamamos Ateliê didático. 


\section{Referências}

BALL, Stephen J. Profissionalismo, Gerencialismo e Performatividade. Cadernos de Pesquisa. São Paulo, v. 35, n. 126, set./dez.2005.

BARBIER, René. A Pesquisa-ação. Brasília: Liber Livros, 2004.

BARDIN, Laurence. Análise de Conteúdo. Lisboa, Portugal; Ediçóes 70, LDA, 2010 .

BRASIL. L.D.B-Lei de Diretrizes e Bases da Educação Nacional: Lei 9394 de 20/12/96. Brasília: Ministério da Educação, 1996.

CUNHA, Maria Isabel. O professor universitário na transição de paradigmas. Araraquara: JM Editora, 1998.

D'ÁVILA, C. Razão e sensibilidade na docência universitária. Em Aberto. Brasília, v. 29, n. 97, p. 103 -118, set./dez, 2016.

- Docência universitária e formação de professores - saberes pedagógicos e constituição da profissionalidade docente. In: Revista Linhas Críticas. Brasília DF, vol. 21, n. 45, p. 467-485, mai/ago, 2015.

. Didática do sensivel: Uma inspiração raciovitalista. Tese para Professor Titular. Salvador, Bahia, Universidade federal da Bahia, 2018.

. Planejamento do processo de ensino e aprendizagem: uma abordagem crítico-construtiva. In: AUTOR; MADEIRA, Ana Verena (orgs.). Ateliê didático: uma abordagem criativa na formação continuada de docentes universitários. Salvador: EDUFBA, 2018a. p. 9-31.

FRANCO, Maria Amélia Santoro. Práticas pedagógicas de ensinar-aprender: por entre resistências e resignações. Educação e Pesquisa. São Paulo, v.41, n.3, p.601-614, jul/set.2015.

GARDNER, H. Estruturas da mente. A teoria das inteligências múltiplas. Porto Algre: Artmed, 1994.

MACEDO, R. S. Etnopesquisa crítica, etnopesquisa-formação. Brasília: Liber Livro Editora, 2006. 
MAFFESOLI, M. Le temps des tribus. Le déclin de l'individualisme dans les sociétés postmodernes. 3. ed. Paris: Ed. La Table Ronde, 2000.

MAFFESOLI, Ml. Éloge de la raison sensible. Paris: Editora La Table Ronde, 2005.

MORIN, E. Introduction à la pensée complexe. Paris, ESF éditeur, 1990.

MORAES, M.C, TORRE, S. Sentipensar - Fundamentos e Estratégias para Reencantar a Educação. Rio de Janeiro: Vozes, 2004.

NÓVOA, A. Formação de professores e trabalho pedagógico. Lisboa, Educa: 2002.

PEREZ, C. L. V. e MIGUEL, C. C. "Fazer" (e narrar) experiência na pesquisa e na formação de professores narradores. Roteiro, Joaçaba, v. 41, n. 1, p. 4166, jan./abr. 2016.

PIMENTA, Selma Garrido; ANASTASIOU, Léa das Graças Camargos. Docência no Ensino Superior. São Paulo: Cortez, 2002.

SANTOS, E.; WEBER, A. Diários online, cibercultura e pesquisa-formação multirreferencial. In: SANTOS, E.; CAPUTO, Stela. G. (Org.). Diários de pesquisa na cibercultura: narrativas multirreferenciais com os cotidianos. Rio de Janeiro: Omodê, 2018.

TARDIF, M. Saberes docentes e formação profissional. Petrópolis: Vozes, 2002. VEIGA, I. P. A. et al. Pós-graduação: espaço de formação pedagógica de docentes para a educação superior. In: AUTOR e VEIGA, I. P. A. (org). Didática e docência na educação superior. Implicaçóes para a formaçáo de professores. Campinas, SP: Ed. Papirus, 2012.

Recebido em: 01 set. 2020

Aceito em: 22 set. 2020 